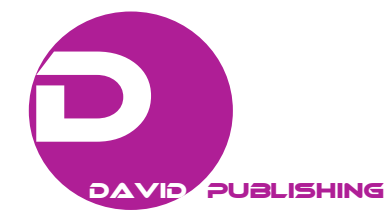

\title{
High Temperature Oxidation of Zr-2.5\%wt Nb Alloys Doped with Yttrium
}

\author{
Djoko Hadi Prajitno ${ }^{1}$, Syoni Soepriyanto ${ }^{2}$, Eddy Agus Basuki ${ }^{2}$ and Slameto Wiryolukito ${ }^{3}$ \\ 1. PTNBR-BATAN, Jl. Tamansari 71 Bandung 40132, Indonesia \\ 2. Metallurgy Engineering, Bandung Institut of Technology, Jl. Ganesa 10 Bandung 40132, Indonesia \\ 3. Materials Engineering, Bandung Institut of Technology, Jl. Ganesa 10 Bandung 40132, Indonesia
}

Received: September 04, 2013 / Accepted: October 6, 2013 / Published: December 25, 2013.

\begin{abstract}
Zirconium base alloys have been utilized in LWRs (light water reactors) as fuel element cladding tubes, fuel assembly spacer grids, guide tubes in PWRs (pressurized water reactors) due to their low neutron absorption and good corrosion resistance. The oxidation resistance of $\mathrm{Zr}$ alloys are strongly controlled by the phase presence and composition of the alloys. The beneficial effect of yttrium content on isothermal oxidation behavior of $\mathrm{Zr}-2.5 \% \mathrm{Nb}-\mathrm{Y}(\mathrm{Y}=0,0.5,1,1.5$ )in wt \% alloy at high temperature has been studied. High temperature oxidation carried out in air furnace at 600,700 and $800{ }^{\circ} \mathrm{C}$ for 1,4 , and 9 h. Characterization by optical microscope showed that microstructure of $\mathrm{Zr}-2.5 \% \mathrm{Nb}-\mathrm{Y}$ alloys relatively unchanged. $\mathrm{X}$-ray diffraction of the alloys depicted that the oxide scale formed during oxidation of zirconium alloys is monoclinic $\mathrm{ZrO}_{2}$ and minor of tetragonal $\mathrm{ZrO}_{2}$, while unoxidized alloy showed two phase $\alpha$ and $\beta$ phase. SEM-EDS examination shows that depletion of Zr composition took place under the oxide layer. Kinetic rate of oxidation of zirconium alloy showed that increasing oxidation temperature will increase oxidation rate but increasing yttrium content in the alloys will decrease oxidation rate. The parabolic rate constant value decreasing with increasing yttrium in $\mathrm{Zr}-2.5 \% \mathrm{Nb}$ alloys.
\end{abstract}

Key words: Oxidation, alloy, zirconium, yttrium.

\section{Introduction}

The Zirconium base alloy have been widely used in the nuclear power plant reactors as cladding material for nuclear fuels due to low neutron absorption and good corrosion resistance. The extension of fuel burn-up has been one of the primary reasons in the NPP (nuclear power plant) to obtain a more economical operation of the reactors. The main restriction on a high burn-up is the WSCI (waterside cladding interaction) where the corrosion of the fuel claddings occurs by primary cooling water reactor at high temperature. Corrosion of zirconium alloys is one of the main factors in the degradation of the nuclear fuel element cladding during service [1, 2]. Zirconium and its alloys oxidized spontaneously and develop of adhesive and

Corresponding author: Djoko Hadi Prajitno, master, research field: nuclear materials. E-mail: djokohp@batan.go.id. protective oxide scale of zirconium at high temperature. At high temperatures the oxidation continues and a uniform oxide layer forms. The kinetics of the scale growth on zirconium is controlled by the intrusion of reactive specious at the scale-base metal interface. Since the oxidation of $\mathrm{Zr}$ alloys is controlled by the diffusion of oxygen to the oxide/metal interface through the scale, the phase present microstructure of the oxide scale is expected to provide the most important data on the oxide growth [3].

Application of alloys at high temperatures should have resistance to chemical degradation caused by reactions oxidation between the alloy and the oxygen. The most structural alloys are not sufficiently protective above $550{ }^{\circ} \mathrm{C}$. Therefore the addition of REE (rare earth elements) to these alloys will improve high temperature oxidation behavior of alloys. The 
effect of REE such as neodymium, yttrium, lanthanum and ytterbium has been studied by Pillis et al. [4]. From that study it was found that the additions of REE improved oxidation behavior of AISI 304L stainless steel. The oxidation behavior at high temperature on low manganese carbon steel after implanted by yttrium has been studied by Caudron et al. [5]. From the study, it can be concluded that implantation of yttrium on low manganese carbon steel improve high temperature oxidation of the alloy. The influence of REE on zirconium alloys was investigated by a number a researcher [6-8]. Bai et al. conducted implantation of yttrium on Zircaloy 4 and oxidized in air furnace at $500^{\circ} \mathrm{C}$. The results showed that implantation yttrium on zircaloy 4 improve oxidation resistant of zircaloy 4 . Peng et al. investigated aqueous corrosion zircalaoy 4 after implanted with yttrium in a $1 \mathrm{~N} \mathrm{H}_{2} \mathrm{SO}_{4}$ [8]. It was found that corrosion resistance of zircaloy 4 in a $1 \mathrm{~N}$ $\mathrm{H}_{2} \mathrm{SO}_{4}$ increase with raising implantation dose.

Zr-Nb alloys , Zirlo, M5 are develop for application in the water cooled reactor. It has been understood that Zirconium added with $\mathrm{Nb}$ show the better corrosion resistance when $\mathrm{Nb}$ content is less than $5 \mathrm{wt} . \%$ by optimizing the heat-treatment $[9,10]$. Depending on the composition and the oxidation conditions, three crystallographic structures have been reported for the $\mathrm{ZrO}_{2}$ layer: monoclinic, tetragonal and in rare cases cubic zirconia. The ratio of different oxide phases has been shown to be dependent on the material composition and on corrosion conditions testing such as temperature, pressure and chemistry composition of gas. The oxidation rate is known to depend on the composition of the material [11] .

In the present study, the high temperature oxidation behavior of $\mathrm{Zr}-2.5 \% \mathrm{Nb}$ dopped with yttrium content 0.5 , 1 , and $1.5 \mathrm{wt} \%$ were investigated under the condition of temperature 700,800 and $900{ }^{\circ} \mathrm{C}$ in air furnace.

\section{Experiments}

\subsection{Specimens Preparation}

The chemical compositions of the $\mathrm{Zr}$ alloys used in this study are the $\mathrm{Zr}-2.5 \% \mathrm{Nb}-\mathrm{X}$ system $(\mathrm{x}=0,0.5,1$, 1.5) were prepared from zirconium sponge (99) $\mathrm{Nb}$ wire (99.9) and Y chip $(99,8)$ in wt\%. The alloys were prepared by an arc melting under a high purity argon atmosphere and remelted at least four times prior to homogenity of the as-cast structure. The arc-melted ingots were $\beta$-treated at $900{ }^{\circ} \mathrm{C}$ for $4 \mathrm{~h}$ in tube furnace under argon atmosphere, and finally hot-rolled after a pre-heating at $900{ }^{\circ} \mathrm{C}$ for $60 \mathrm{~min}$. The chemical composition of the $\mathrm{Zr}-2.5 \% \mathrm{Nb}-\mathrm{Y}$ alloys used in this study is given in Table 1 .

\subsection{Oxidation Testing}

The oxidation tests in air furnace were conducted by using tube furnace in the range temperature from 600 to $800{ }^{\circ} \mathrm{C}$ with the duration in furnace 1,4 and $9 \mathrm{~h}$. The oxidation behavior of the alloys was examined by measuring the weight gain of the sample as a function of the exposure time. After the oxidation test, the cross-section of the oxide was observed by a transmitted light optical microscopy. X-ray diffraction is used for characterization oxidized and un oxidized specimens. For the optical microscope examination, the specimen embedded in an epoxy resin and then the surfaces of the sections were mechanically grinding from grit 800 to 2,400. Micro structural analysis of specimen was carried out by using an optical microscope after specimen chemically etched in a solution of $5 \% \mathrm{H}_{2} \mathrm{SO}_{4}, 10 \% \mathrm{HF}, 30 \% \mathrm{HNO}_{3}$ and $55 \%$ $\mathrm{H}_{2} \mathrm{O}$ by volume. Cross sections composition of the specimen were analyzed by SEM-EDS

\section{Results and Discussion}

\subsection{Microstructures as Hot Roll Alloys}

Fig. 1 showed microstructures of as hot roll three

Table 1 Chemical composition of $\mathrm{Zr}-2.5 \% \mathrm{Nb}-\mathrm{Y}$ alloys (wt\%).

\begin{tabular}{llll}
\hline Specimens & $\mathrm{Zr}$ & $\mathrm{Nb}$ & $\mathrm{Y}$ \\
\hline Alloy-1 & 97.5 & 2.5 & 0 \\
Alloy-2 & 97 & 2.5 & 0.5 \\
Alloy-3 & 96.5 & 2.5 & 1 \\
Alloy-4 & 96 & 2.5 & 1.5 \\
\hline
\end{tabular}



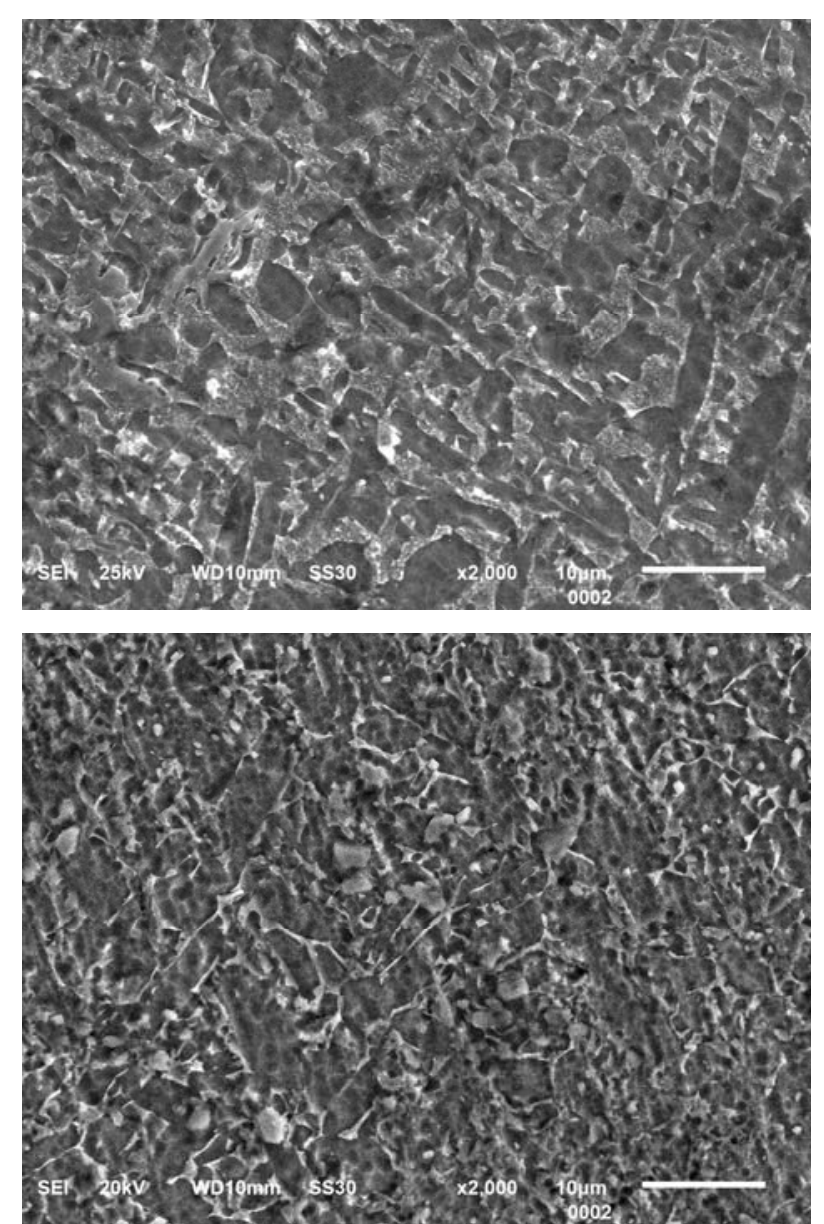

Fig. 1 Microstructures 2 different alloys $\mathrm{Zr}-2.5 \% \mathrm{Nb}$ andZr-2.5\% Nb-1\%Y after hot roll.

different alloys $\mathrm{Zr}-2.5 \% \mathrm{Nb}$, and $\mathrm{Zr}-2.5 \% \mathrm{Nb}-1 \% \mathrm{Y}$. From the figure depicted that the microstructures of three alloys are relatively the same in apparent. The alloys consist of dendritic microstructure with interdendritic toward rolling direction.

\subsection{Oxidation Kinetics}

Due to the growth of zirconium oxide scale is controlled by diffusion oxygen inward through oxide scale so the phase present and microstructure of oxide scale plays an important role in the oxidation kinetic. Moreover, the pore, crack and defect of surface oxide scale may also responsible to the oxidation kinetics. The oxidation kinetic of $\mathrm{Zr}-2.5 \% \mathrm{Nb}$ and $\mathrm{Zr}-2.5 \% \mathrm{Nb}-\mathrm{Y}$ with yttrium addition $0.5,1,1.5 \mathrm{wt} \%$ shows significant different. Fig. 2 shows the weight gains of $\mathrm{Zr}-2.5 \% \mathrm{Nb}-\mathrm{Y}$ oxidized at different temperature and time. In the $600{ }^{\circ} \mathrm{C}$, the growth of zirconium oxide scale is controlled by diffusion of oxygen through the oxide layer. There is different value of weight gain observed at different alloys. Addition $\mathrm{Y}$ in the alloys will decrease the weight gain. In other word, additional $\mathrm{Y}$ in the alloys will improve resistance oxidation of its alloy as seen in Fig. 4a. Compared with the oxidation weight gain of un doped $\mathrm{Zr}-2.5 \% \mathrm{Nb}$, it can be shown that the oxidation kinetic rate decreases with increases

Table 2 The metallic phase present of $\mathrm{Zr}-2.5 \%$-Y alloys as Hot-roll.

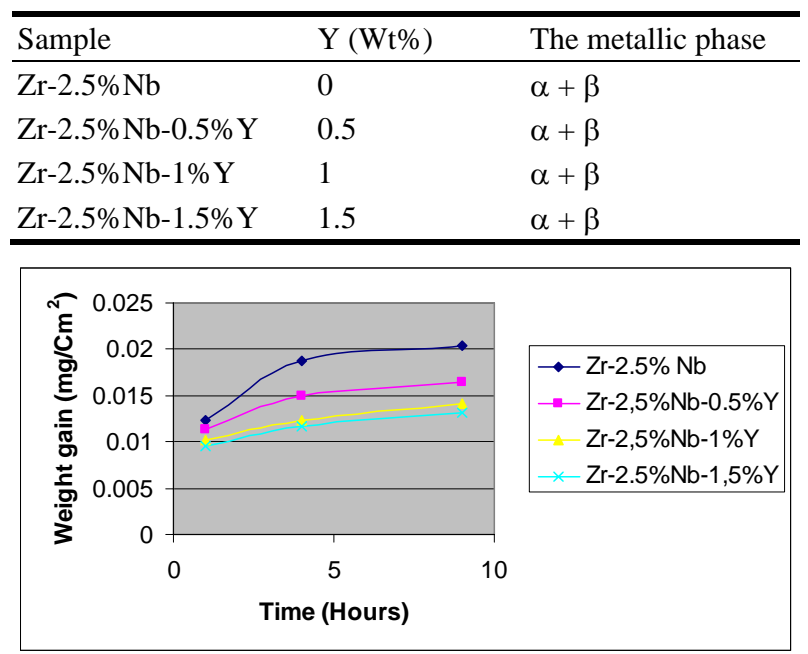

(a)

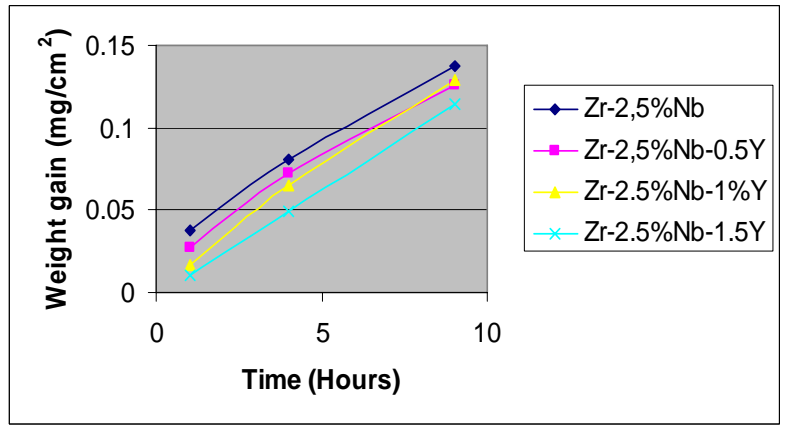

(b)

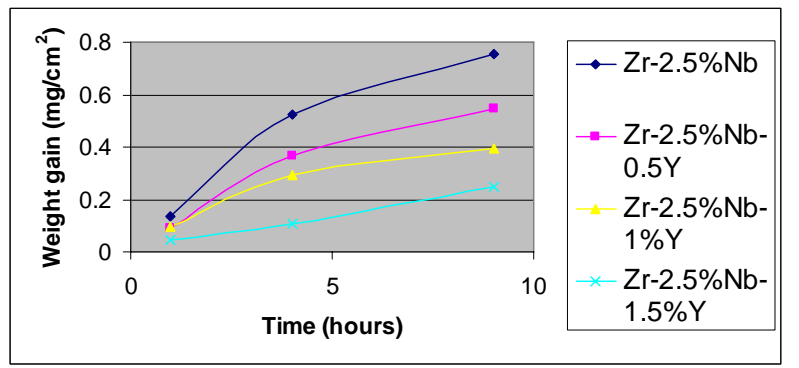

(C)

Fig. 2 Oxidation rate as hot roll alloy at 600 (a), 700 (b) and $800{ }^{\circ} \mathrm{C}(\mathrm{c})$. 
$\mathrm{Y}$ addition. The curve with addition $1.5 \% \mathrm{Y}$ of $\mathrm{Zr}-2.5 \% \mathrm{Nb}$ below curve un doped $\mathrm{Zr}-2.5 \% \mathrm{Nb}$ indicated that oxidation resistance of doped $\mathrm{Zr}-2.5 \% \mathrm{Nb}$ is lower compared with un doped $\mathrm{Zr}-2.5 \% \mathrm{Nb}$.

Kinetic oxidation rate was higher at higher temperature than $600{ }^{\circ} \mathrm{C}$. As expected that temperature will accelerated reaction oxidation rate. The alloys exhibiting unstable oxide growth also increased with temperature. The relationship between oxidation weight gain and $\mathrm{Y}$ content in the alloy showed that changes in alloying content caused significant differences in high temperature oxidation behavior. The Z-2.5\%Nb-Y alloys with high $\mathrm{Y}$ content more resistance oxidation compare with $\mathrm{Zr}-2.5 \% \mathrm{Nb}$ alloys. Some $\mathrm{Zr}-2.5 \% \mathrm{Nb}-1 \% \mathrm{Y}$ alloys showed stable oxide growth with protective behavior compared with Zr-2.5\%Nb Alloy. From EDS analysis, composition of $\mathrm{Zr}$ beneath the oxide scale showed that alloy with $\mathrm{Y}$ contain $85,53 \mathrm{wt} \%$ while $\mathrm{Zr}-2.5 \% \mathrm{Nb}$ alloy contain $78 \%$. It means that outward diffusion of $\mathrm{Zr}$ relative small for $\mathrm{Zr}-2.5 \%-1 \% \mathrm{Y}$ compared with $\mathrm{Zr}-2.5 \% \mathrm{Nb}$ alloy. Oxygen inward diffusion decreased due to development oxide scale $\mathrm{Y}_{2} \mathrm{O}_{3}$ for $\mathrm{Y}$ doped $\mathrm{Zr}-2.5 \%$ $\mathrm{Nb}$ alloy during oxidation. Similar to my results, it has been reported that the oxidation resistance of zircalloy could be improved by addition rare earth element such as yttrium and cerium [11]. The results show that development tetragonal phase of zirconia took place if the alloy contain yttrium.

The weight gain due to oxidation as function of time related to parabolic rate law :

$$
\mathrm{W}^{2}=\mathrm{Kpt}
$$

where $\mathrm{W}\left(\mathrm{mg} \cdot \mathrm{cm}^{-2}\right)$ is weight gain, and $\mathrm{Kp}\left(\mathrm{mg}^{2} \mathrm{~cm}^{-2} \mathrm{~s}^{-1}\right)$ the parabolic rate constant, and $\mathrm{t}(\mathrm{s})$ the oxidation time. The parabolic rate constant obtained by Eq. (1) are tabulation in Table 3. Parabolic rate constant for $\mathrm{Zr}-2.5 \% \mathrm{Nb}$ more lower compared with $\mathrm{Zr}-2.5 \% \mathrm{Nb}$ doped with yttrium at all temperature. Its mean that inward diffusion oksigen in oxide scale in undoped Zr-2.5\%Nb alloy more higher compared with doped alloy. Early studies by Arima shows that the value parabolic rate constant for $\mathrm{Zr}-2.5 \% \mathrm{Nb}$ alloy at temperature $800{ }^{\circ} \mathrm{C}$ was 0.17 while in this experiment 0.1624 .

Fig. 3 shows the $\mathrm{X}$-ray diffraction patterns for $\mathrm{Zr}-2.5 \% \mathrm{Nb}$, and $\mathrm{Zr}-2.5 \% \mathrm{Nb}-1.5 \% \mathrm{Y}$ before oxidation (a) and $\quad \mathrm{Zr}-2.5 \% \mathrm{Nb}, \quad \mathrm{Zr}-2.5 \% \mathrm{Nb}-0,5 \% \mathrm{Y}$, $\mathrm{Zr}-2.5 \% \mathrm{Nb}-1 \% \mathrm{Y}$ and $\mathrm{Zr}-2.5 \% \mathrm{Nb}-1.5 \% \mathrm{Y}$ after oxidized at $800{ }^{\circ} \mathrm{C}$ for $1 \mathrm{~h}$ (b). In Fig. 3a, it can be seen that the diffraction patterns showed the presence of $\alpha$ and $\beta$ zirconium phase before the alloy was oxidized. After oxidation the main oxide dominated by monoclinic zirconia's phases $\mathrm{ZrO}_{2}$. Although the surface of this specimen was most oxidized other phases could be observed in the diffraction patterns of tetragonal zirconium, $\mathrm{Nb}_{2} \mathrm{O}_{5}$ and $\mathrm{Y}_{2} \mathrm{O}_{3}$ phase are shown in Fig. 3.

\section{SEM-EDS Cross Section Oxidized Alloys}

SEM-EDS examination cross section oxidized alloy

Table 3 Parabolic rate constants at 600,700 and $800{ }^{\circ} \mathrm{C}$.

\begin{tabular}{llll}
\hline Paduan & \multicolumn{3}{c}{ Suhu $\left({ }^{\circ} \mathrm{C}\right)$} \\
\cline { 2 - 4 } & 600 & 700 & 800 \\
\hline Zr-2.5 Nb & 0.0002 & 0.051 & 0.1624 \\
Zr-2.5\%Nb-0,5\% Y & 0.00001 & 0.042 & 0.0838 \\
Zr-2.5\%Nb-1,0\% Y & 0.00007 & 0.042 & 0.0462 \\
Zr-2.5\%Nb-1.5\% Y & 0.00006 & 0.032 & 0.0151 \\
\hline
\end{tabular}

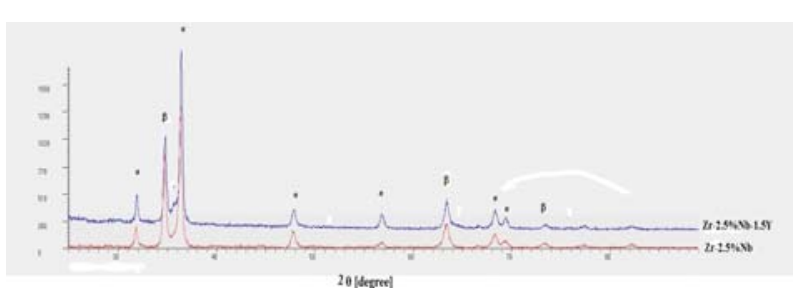

(a)

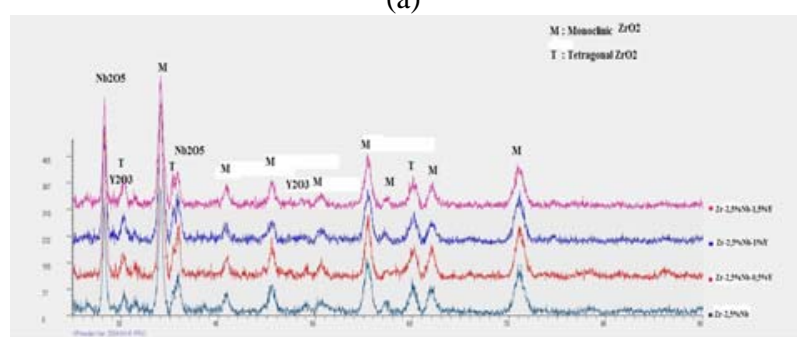

(b)

Fig. 3 XRD patterns (a)before oxidation alloy $\mathrm{Zr}-2.5 \% \mathrm{Nb}$ and $\mathrm{Zr}-2.5 \% \mathrm{Nb}-1.5 \% \mathrm{Y}$ (b)after oxidized at $800{ }^{\circ} \mathrm{C}$ for 1 h-2.5\%Nb, Zr-2.5\%Nb-0,5\%Y Zr-2.5\%Nb-1\%Y and Zr-2.5\%Nb-1.5\%Y. 

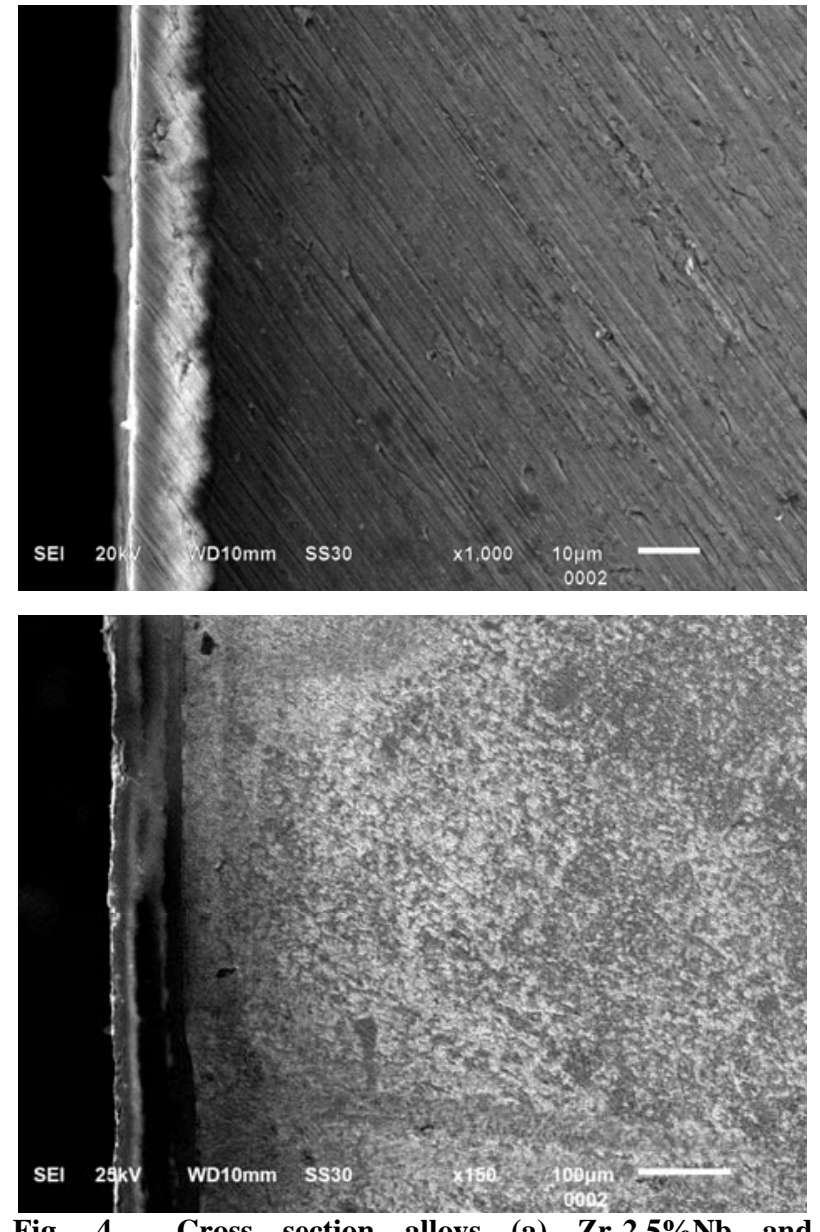

Fig. 4 Cross section alloys (a) $\mathrm{Zr}-2.5 \% \mathrm{Nb}$ and (b)Zr-2.5\% Nb-1.5\%Y after oxidation at 700 for $9 \mathrm{~h}$.

Zr-2.5\%Nb and Zr-2.5\%Nb-1.5\%Y after oxidation at $700{ }^{\circ} \mathrm{C}$, for $9 \mathrm{~h}$ are showed in Fig. 4. It is seen that increases oxidation temperature will increase the width of oxide layer. The oxide layer formed on the surface alloy free of pore and dense. Depleted zone in $\mathrm{Zr}-2.5 \% \mathrm{Nb}$ after oxidation at $700{ }^{\circ} \mathrm{C}$ for $9 \mathrm{~h}$ contain 78.8wt\%Zr. The Zr-2.5\%Nb-1.5\%Y alloy was oxidized at $700{ }^{\circ} \mathrm{C}$ for $9 \mathrm{~h}$ and depleted zone of the alloys contain $85.53 \mathrm{Zr}$. It can be concluded that addition yttrium on $\mathrm{Zr}-2.5 \% \mathrm{Nb}$ alloy improve oxidation resistant at high temperature.

\section{Conclusions}

High temperature oxidation tests were conducted for Zr-2.5\%Nb doped and undoped with yttrium at 600, 700 and $800{ }^{\circ} \mathrm{C}$. The oxidation kinetic related to parabolic rate law and the weight gains of the dopped $\mathrm{Zr}-2.5 \% \mathrm{Nb}$ samples with yttrium were smaller than that of undopped $\mathrm{Zr}-2.5 \% \mathrm{Nb}$ and the higher yttrium dopped the better the oxidation resistance. Xrd analyses showed that the oxides of $\mathrm{Y}, \mathrm{Nb}$ and $\mathrm{Zr}$ existed in the form of $\mathrm{Y}_{2} \mathrm{O}_{3}, \mathrm{Nb}_{2} \mathrm{O}_{3}$ and $\mathrm{ZrO}_{2}$. The mechanism of the oxidation behavior improvement of $\mathrm{Zr}-2.5 \% \mathrm{Nb}$ doped by yttrium addition was due to the role of $\mathrm{Y}_{2} \mathrm{O}_{3}$. Parabolic rate constant undoped alloy with $\mathrm{Y}$ higher than doped alloy with Y.

\section{Acknowledgments}

This study is part of my research programs and funded by PTNBR-National Nuclear Energy Agency.

\section{References}

[1] J. Lin, H. L. Li, and J. A. SZpunar. Mater. Scien. Eng. A 381 (2004): 104-112.

[2] N. Ni, S. L. Perez, and M. Jenkins. Scripta Materialia 62 (2010): 564-7.

[3] T. Arima, and et al. Corrosion Science 47 (2009): 435.

[4] M. F. Pillis, and et al. Mat. Res. 9 (2006): 4.

[5] E. Coudron, and H. Buscail. Applied Surface Science 158 (2000): 310-329.

[6] J. Xu, X. Bai, and Y. Fan. J. Mater. Sci. 35 (2000): 6225-9.

[7] X. Bai, J. Xu, A. Jin, F. He, and Y. Fan. Nuclear Instrumen and Methods in Physic Research B 160 (2000): 49-53.

[8] D. Q. Peng, and et al. Applied Surface Science 221 (2004): 259-271.

[9] R. J. Perez, and A. R. Masih. Journal Nuclear Materials 360 (2007): 242-254.

[10] S. A. Nikuli, and et al. Journal Nuclear Materials 418 (2011): 1-7.

[11] T. Arima, and et al. Progress in Nuclear Energy 51 (2009): 307-312. 